\title{
Understanding the Barriers That Slow Firms Shifting from Products to Services
}

Just in case you have any doubt about the importance of services to a manufacturing business, Fig. 1.1 shows the contributions made by equipment sales and service sales for typical manufacturing firms (producing durable goods for business-to-business or B2B - markets). In absolute terms, the total margins are very close in size to each other. However, due to design and development costs, there are much larger risks associated with new equipment than with services. This makes it all the more important to make the shift to services and capture new sales as well as learning to combine products with services to create a product-service system (PSS).

There is also a virtuous circle, where improved service experience increases the chance, that the customer will buy from you again. It means that development teams can get more relevant feedback from the customer, either directly or indirectly, through the field service teams. Services are also generally less impacted by the economic cycles than product businesses, because product sales are often driven by "boom-and-bust" CAPEX (or capital expenditure) cycles, whereas services are driven by gross domestic product (GDP) cycles and firms' OPEX (or operating expenditure) spends. This means services can give a firm a more stable long-term cash flow based on servicing the products sold in the past (Gebauer, 2007; Kowalkowski et al., 2017).

\subsection{How This Book Works}

Before moving on, we think it is worth explaining how this book works. It does not have to be read from beginning to end. In fact, we could not imagine many people doing that. It is a cookbook that uses actual cases to offer approaches to overcome individual barriers that can slow the move to services. Indeed, there is no single journey to services for firms, as each approach is context specific. Because of this, we focus on the barriers and provide some examples of how they were overcome. We have also included the tools that we think could help managers and practitioners 


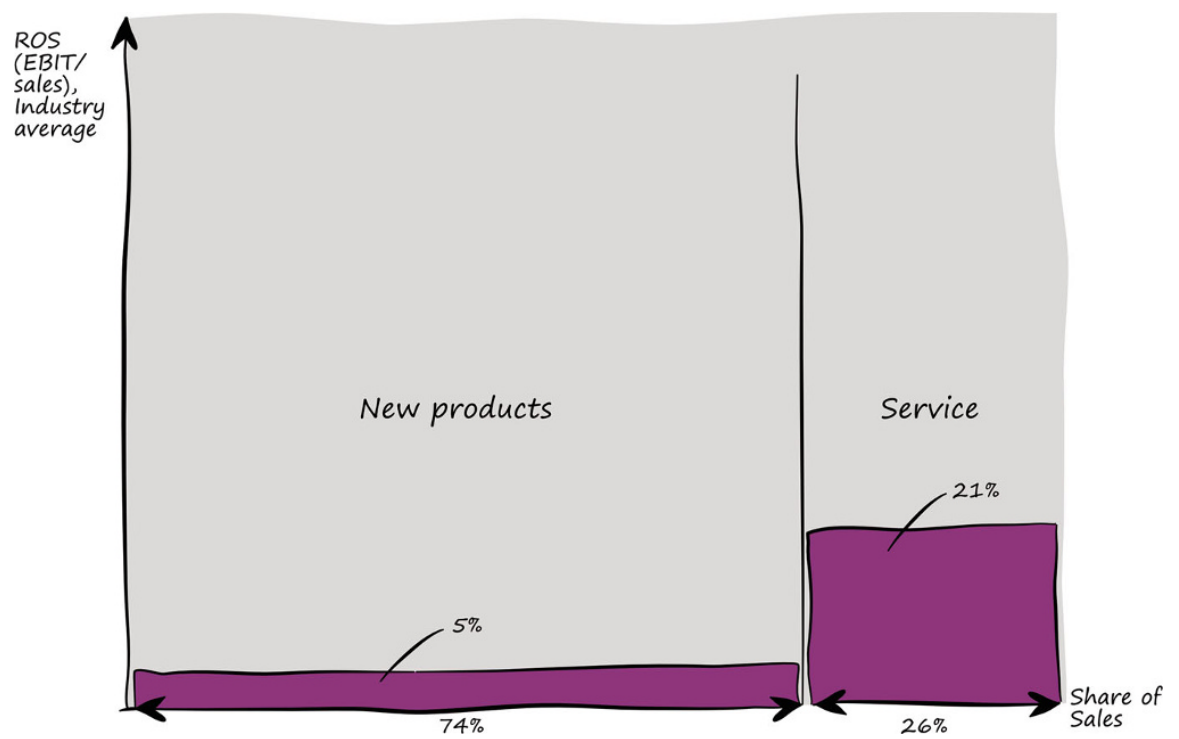

Fig. 1.1 The contribution to sales and margin for typical manufacturing firms (illustration by Annick Holland, adapted from Schmiedeberg et al., 2010)

analyze a specific situation and deal with the seven distinctive categories of barriers (Fig. 1.2) that have been found by research (Hou \& Neely, 2013):

\section{Customers}

2. Organizational structure and culture

3. Knowledge and information

4. Products and activities

5. Competitors, suppliers, and partners

6. Economics and finance

7. Society and environment

The individual barriers have been identified from surveys and direct observations we carried out in several companies experiencing a servitization journey. Over the 3 years we spent on this research, we had the opportunity to talk to many operators and collect hints and tips from over 200 different discussions and chats, as well as over 30 complete interviews (West \& Gaiardelli, 2016; West et al., 2014). This was backed up with our own personal experiences and interactions with service leaders as well as the frontline people who are often the most visible aspect of delivering a service (Fig. 1.3). Of course, we published and presented the results of our research in scientific conference proceedings and journals (we are academics), but we also want to make what we have learned accessible to managers who face these barriers on a daily basis, which is why we have collected all our findings in this book. 


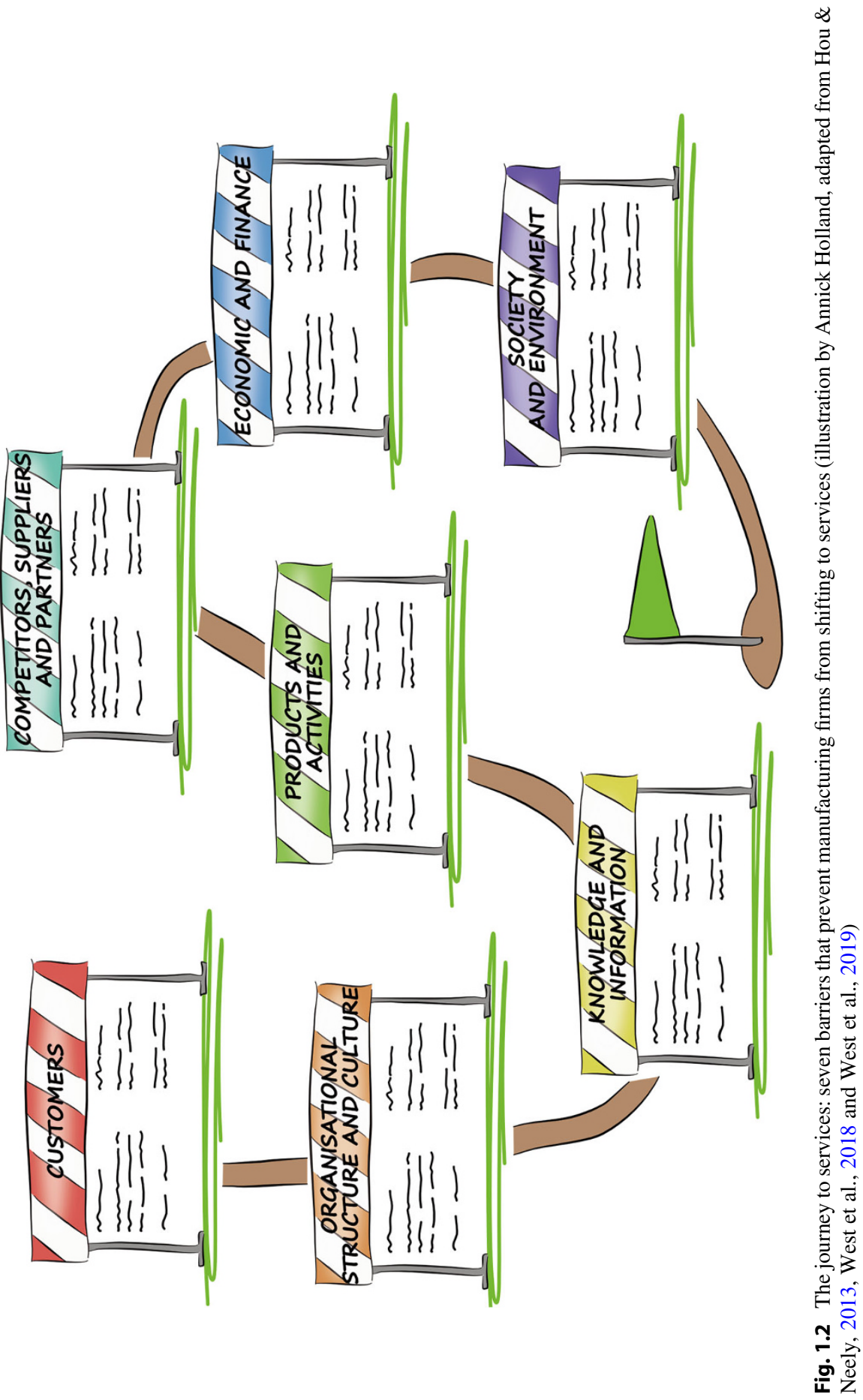


Fig. 1.3 Experienced service leaders contributed to this book (illustration by Annick Holland, authors' work)

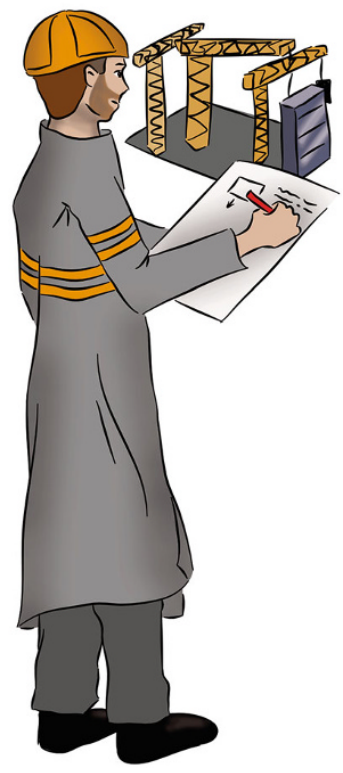

\subsection{Product-Service Systems and Servitization}

In the past, many firms focused only on the value related to products, and they often provided services for free, viewing them as a cost or a "necessary evil" (Mathieu, 2001; White et al., 1999). Over the years, an increasing number of manufacturing companies have begun to understand the importance of services as a source of profit and a way to differentiate one company from another to gain a commercial advantage. This has led them to propose increasingly sophisticated, integrated productservice solutions. In research, literature and practice, the concept of "servitization of manufacturing" has become the common term to describe the business model's continuum from a pure product orientation toward an integrated product-service system (or PSS) as shown in Fig. 1.4. Many firms continue to consider service as a cost and make the customer happy "tool" to ensure other sales or the performance, whereas others are moving from "free" to "fee" and, in doing so, journeying along the servitization transition.

Today, several manufacturers are designing and selling complex product-service systems. Notable examples are Rolls-Royce with aeroengines, Hilti with power tools for construction sites, Ricoh with photocopiers, Caterpillar with construction machinery, ABB with ship turbo compressors, and GE with power plant. With each of these examples, the manufacturer's products and services are bundled together in one form or another. 


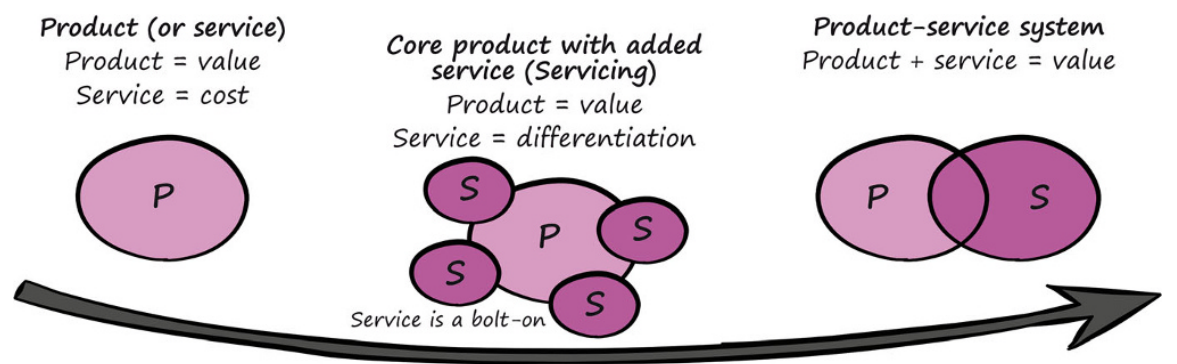

Increasing servitisation

Fig. 1.4 The stages of the product-service system continuum (illustration by Annick Holland, adapted from Vandermerwe \& Rada, 1988)
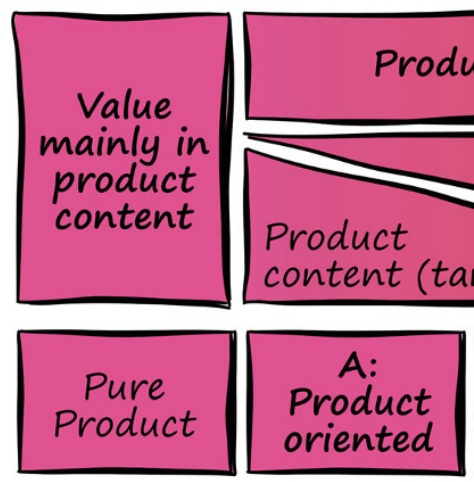

\section{Product-service system}
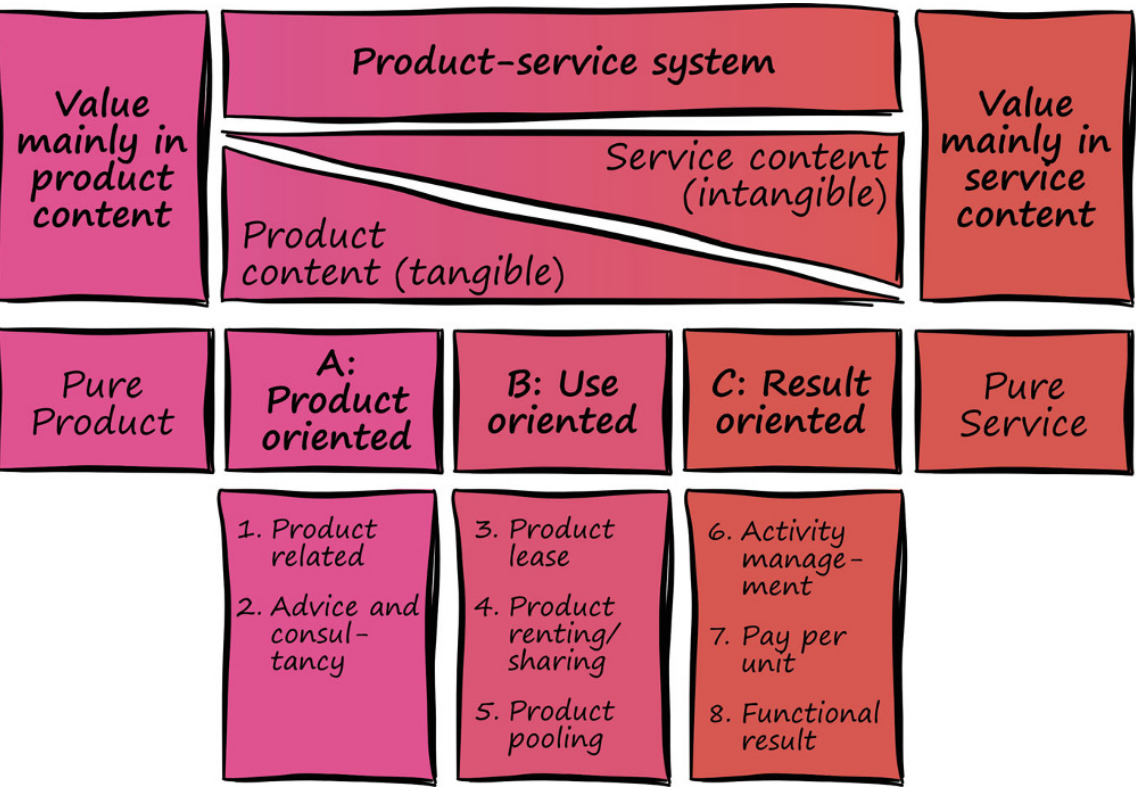

Fig. 1.5 The stages of the product-service system continuum (illustration by Annick Holland, adapted from Tukker, 2004)

Many researchers have tried to describe the characteristics of product-service systems through several models, frameworks, and schemes. Tukker's (2004) model shown in Fig. 1.5 is probably one of the most famous and widely used. Created to describe types of PSSs and their revenue models, working from left to right, this model shows a service transition. It also gives different perspectives (e.g., the role of the asset owner, the manufacturer, the operator, the service provider). 
Many product-service system-based business models today are still product oriented, as companies are still geared to selling products and providing services during their lifecycle. In this case, services fall into two general areas: (1) maintenance services and (2) operational services. In both cases, services are usually bundled as a complete package in a service contract, where the customer and the supplier form a long-term relationship. The supplier still receives transactional revenues from the sale of the product. However, under this business model, instead of transactional onetime revenues for the services, recurring revenues are received for the bundled services. Often, both operations and maintenance services can be packed together.

Also, maintenance services fall into two different models. In the first model, maintenance is provided through a simple model based on a call-off contract with pre-agreed fees for parts and services, where the customer takes responsibility for performance, including unplanned maintenance. In the second model, the service is based upon a more complex scenario, where the supplier takes more responsibility, often including both planned and unplanned maintenance as well as other performance commitments. In these more complex agreements, the supplier receives use-based fees and takes the risks of equipment breakdown, as performance commitments (e.g., availability) are provided on the equipment. Taking over the responsibility of the equipment, providing uptime, and preventing failures, requires the supplier to engage in risk and cost management, as well as to develop new methods and technologies to enhance a continuous and even remote control of the product's technical conditions. Rolls-Royce's "power-by-the-hour" model falls into this more complex maintenance service agreement.

Operational services, instead, need the supplier to take over the management of operations, which usually are taken care of by the customer. This calls for more detailed knowledge of the customer's processes. Among others, operational services may include training services to help the customer maintain the product correctly and required maintenance personnel to manage the equipment. Other firms extend this, yet further, to include the operation of the customer's equipment, which is often called operations and maintenance (O\&M) in some segments. Many hybrid models exist with operations support, such as mentoring services and asset management support, where the roles and responsibilities of the traditional manufacture/customer deviates considerably from the traditional relationships.

In the case of "use-oriented product-service system," the product is no longer sold to the customer, as its use is delivered to the customer, without the responsibilities of ownership. This means that the supplier does not sell its product; rather, both product and services are integrated into a package based on the actual usage or availability of the equipment to the customer. The supplier is fully responsible for the correct functioning of the product, since it still owns the product. In this situation, the supplier must have the financial resources to own the assets. Hilti provides a good example of this.

In a more sophisticated product-service system, such as a "result-oriented product-service system," the customer and supplier agree on a certain functionality or outcome, with the supplier maintaining full responsibility to deliver this. 


\begin{tabular}{|c|c|c|c|c|c|}
\hline $\begin{array}{l}\text { Spare } \\
\text { Parts }\end{array}$ & $\begin{array}{l}\text { Spare parts (OEM) } \\
\text { Express logistics } \\
\text { Client specific stocking }\end{array}$ & $\begin{array}{l}\text { Spare parts } \\
\text { for } \\
\text { accessories }\end{array}$ & $\begin{array}{l}\text { Wearables } \\
\text { Spare parts for } \\
3 \text { rd party }\end{array}$ & $\cdots$ & Basic Services \\
\hline $\begin{array}{l}\text { Mainte- } \\
\text { nancel } \\
\text { repair }\end{array}$ & $\begin{array}{l}\text { Break/Fix } \\
\text { Maintenance } \\
\text { Inspection }\end{array}$ & $\begin{array}{l}\text { Remote } \\
\text { moni- } \\
\text { toringl } \\
\text { fixing }\end{array}$ & $\begin{array}{l}\text { 3rd party repair } \\
\text { Spare parts for } \\
\text { 3rd party }\end{array}$ & $\cdots$ & $\begin{array}{l}\text { Automatic demand } \\
\text { by client }\end{array}$ \\
\hline $\begin{array}{l}\text { Perform. } \\
\text { increase }\end{array}$ & $\begin{array}{l}\text { Updates } \\
\text { Upgrades }\end{array}$ & $\begin{array}{l}\text { formance } \\
\text { it }\end{array}$ & $\begin{array}{l}\text { 3rd party } \\
\text { upgrade }\end{array}$ & $\ldots$ & \\
\hline Consulting & Dimensioning & tory planning & & $\cdots$ & \\
\hline Pperation & $\begin{array}{l}\text { Rentals } \\
\text { Facility } \\
\text { management }\end{array}$ & $\begin{array}{l}\text { erim } \\
\text { nagement }\end{array}$ & $\begin{array}{l}\text { Technical } \\
\text { operations }\end{array}$ & $\cdots$ & $\begin{array}{l}\text { Lifecycle Services } \\
\text { Demand to be } \\
\text { stimulated }\end{array}$ \\
\hline $\begin{array}{l}\text { Installa- } \\
\text { tion }\end{array}$ & $\begin{array}{l}\text { On-site } \\
\text { installations }\end{array}$ & $\begin{array}{l}\text { tem } \\
\text { egration }\end{array}$ & & $\cdots$ & \\
\hline Training & Training centre & $\begin{array}{l}\text { ubleshoot } \\
\text { kshop }\end{array}$ & $\begin{array}{l}\text { On-site training/ } \\
\text { coaching }\end{array}$ & $\cdots$ & \\
\hline
\end{tabular}

Fig. 1.6 Types of services: a set of basic services needed to keep equipment operational and different lifecycle services where demand needs to be stimulated (illustration by Annick Holland, adapted from Schmitt \& Sipen, 2017)

Ownership of the equipment required for delivering the service remains with the supplier, so it is closely related to "use-oriented PSS." An example is the delivery of a "pleasant climate" as a service, instead of selling heating, ventilation, and cooling equipment.

Services can also be classified in relation to how their demand is created. Indeed, some of the services can be automatically demanded (e.g., planned inspections), whereas others require a callout service (unplanned events), and others need the owner or operator to be encouraged (e.g., training services or upgrades). However, too often, companies focus on the basic services without considering the product and/or customer lifecycle. Figure 1.6 provides a list of services that may be required over the operational life of the equipment, based on Schmitt and Sipen (2017).

A complementary perspective on Tukker's (2004) model is provided by Kowalkowski and Ulaga (2017), who consider the nature of the value proposition and the service recipient. Specifically, services can be classified by the supplier's promise to perform (input based) instead of the customer aiming to achieve a target (output based). Moreover, they can be oriented toward the supplier's goods instead of the customer's processes of the services, as shown in Fig. 1.7.

A further interesting perspective on product-service systems (PSSs) can come from considering a traditional product lifecycle, where there are many people providing many services to many different pieces of equipment or products (Fig. 1.8). During the operational life of a piece of equipment, spares, consumables, 


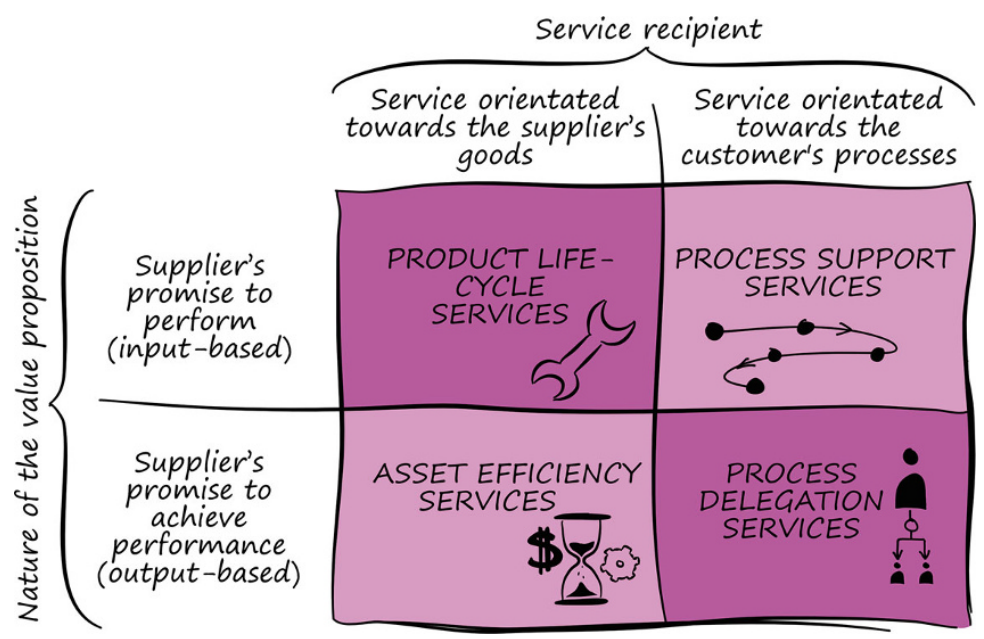

Fig. 1.7 Service classification (illustration by Annick Holland, adapted from Kowalkowski \& Ulaga, 2017 and Kowalkowski \& Witell, 2020)

and services are needed to ensure safe and reliable operation of the machine. Generally, these are based on a planned maintenance schedule; however, there are also unplanned events that can mean the plan has to change. Late in the operational cycle of the equipment, upgrades may be offered, which change the status and the capability of the equipment. This is in effect a very complex model.

Perspectives are always important, and with servitization it is fundamental to understand how they fit together. Figure 1.9 shows this for a coffee machine manufacturer (what we call the original equipment manufacturer or OEM) and its customer. The owner/operator's view is shown horizontally as the supply chain from beans to coffee. Here, the main value creation processes are based on transforming the coffee beans into a drink, which they sell. The coffee shop's key outcome (or purpose) is to provide good-quality coffee, and the OEM can support them in several different ways. The coffee machine manufacturer (OEM) can provide the following: consumables, spares, and maintenance when requested, machine process parameter monitoring to ensure consistency of coffee quality, and even fleet monitoring to allow optimization of machines based on production volumes.

Instead, the OEM's product perspective is shown as a vertical silo. Here, the owner of the coffee machine buys it to make coffee, which s/he sells. By considering the different perspectives and the different service classifications along with the detailed types of services, new value propositions can be imagined, as in the example here. Similar considerations can be made for trains, planes, and automobiles as well as ships, oil refineries, power plant, and photocopiers... the different types of products with services and their markets are endless. 


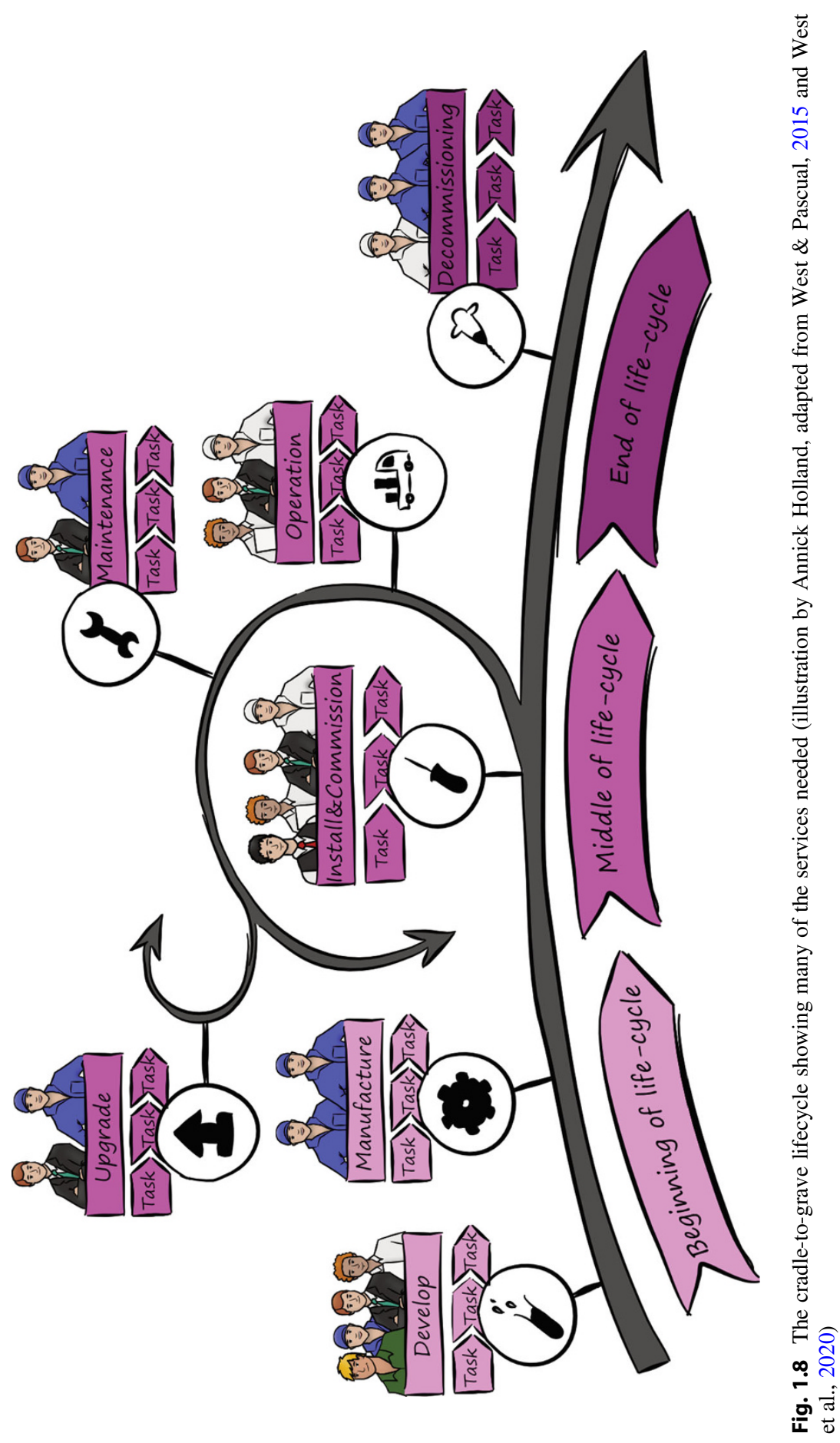




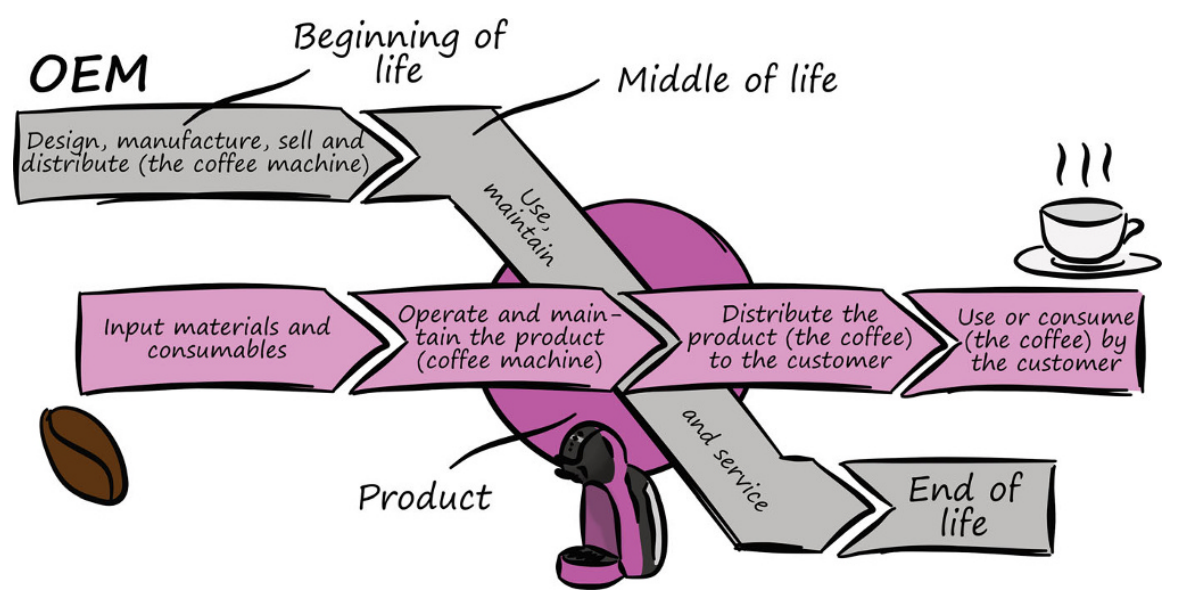

Fig. 1.9 Different perspectives: the operator's supply chain and the OEM's product silo (illustration by Annick Holland, authors' work)

\subsection{The Journey to Services}

The development of new services is not like new product development (NPD), and this is where the problem starts for many manufacturing firms. Indeed, service transformation creates a major disruptive change in a business, as it is really a journey that requires the implementation of a change management process. The barriers that firms face are both contextual (Dmitrijeva et al., 2020) and created from paradoxes (Brax, 2005; Kohtamäki et al., 2020) and involve both large and small firms (Confente et al., 2015). Strategically, senior management in a business likes the idea of services, because customers ask for them and because margins are usually higher than in traditional product sales. However, senior management generally makes this strategic decision without fully understanding how to overcome the barriers that could slow the journey into service. Strategy is often delivered through a set of loosely coordinated actions (Lütjen et al., 2017; Rabetino et al., 2017).

The journey to services is often bumpy. The Cambridge Service Alliance (Martinez et al., 2016) identified seven success factors that help improve the success of service transition for manufacturing firms:

1. Assess the market and internal readiness: making the shift to services means that all parties involved must be ready to change and understand the value of doing so.

2. Create the right strategic and cultural context: a service business is different to a product business and needs a completely new mindset to be instilled throughout the whole service ecosystem.

3. Build the structures and governance for services: firms need to make a clear commitment to services by creating properly empowered teams and the appropriate organizational structures. 
4. Get the resources ready for service innovation and delivery: short- and long-term budgets need to acknowledge that services are very resource intensive and change over time.

5. Proactively manage engagement and trust: services are co-created and often co-delivered with customers who are active participants in the service journey.

6. Develop and embed service processes: firms delivering services must experiment and adapt, and they need processes that enable them to do that.

7. Optimize services and communicate best practices: services rely on continuous innovation and so require a "best-practice" mindset.

These are seven statements to assess the strategic aspirations of the firm, yet they do not necessarily address the barriers that delay, slow, or prevent a product-oriented firm from shifting to services.

\subsection{Learning to Understand Complex Systems}

Some terms we use in this book, such as "users, end-users, installers, distributors, owners, and manufacturers," come from the language that is used in many manufacturing firms (Fig. 1.10). This is because many manufacturers have complex relationships with the people who benefit from the products they make and the

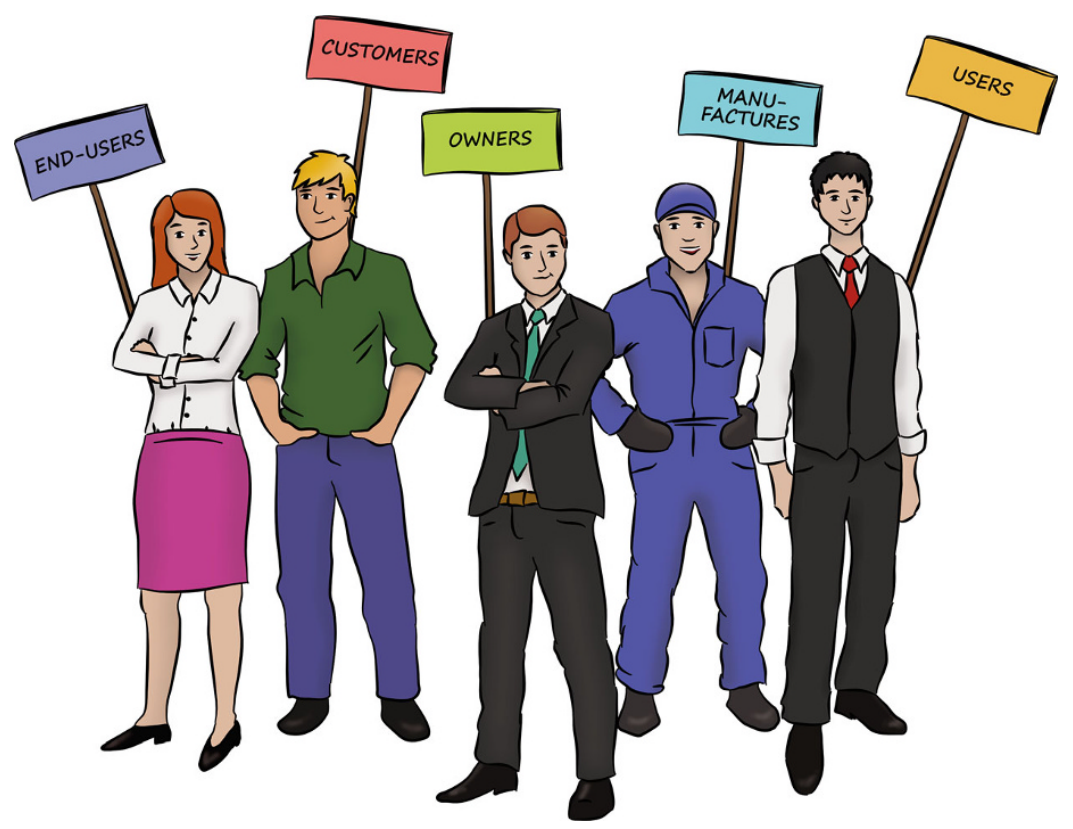

Fig. 1.10 The community of users, end-users, customers, owners, and manufacturers (illustration by Annick Holland, authors' work) 


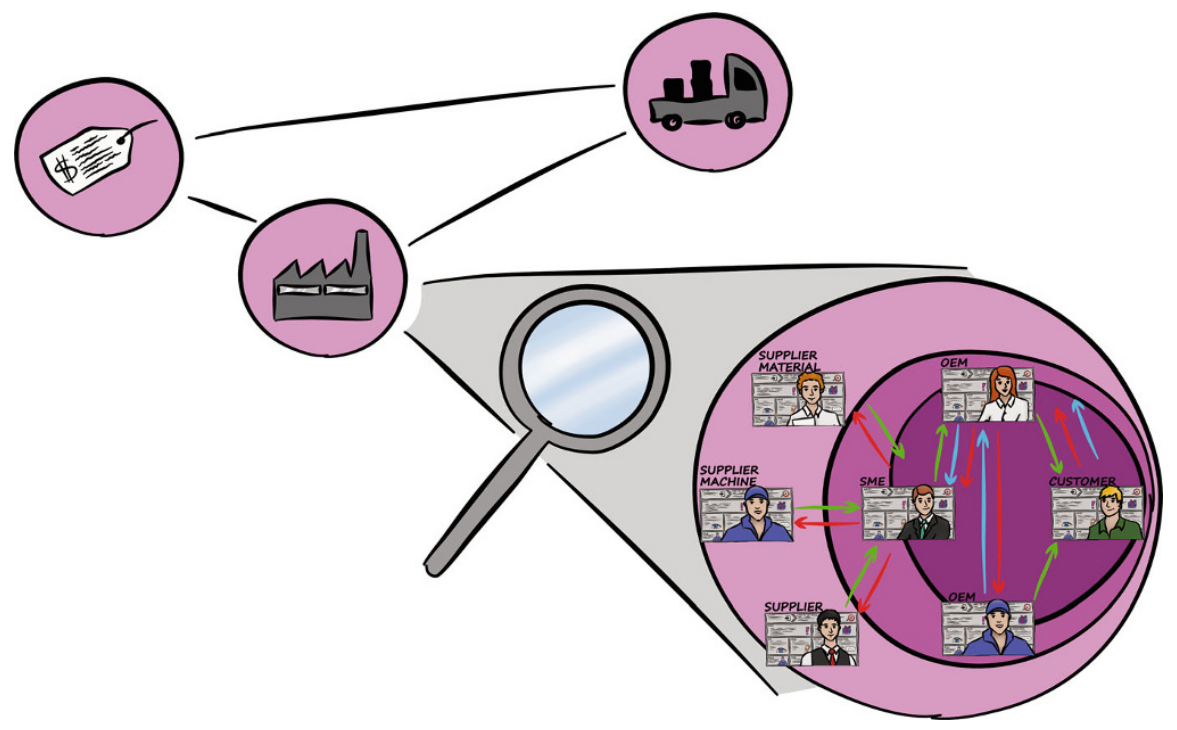

Fig. 1.11 Learning to understand complex B2B environments (illustration by Annick Holland, authors' work)

services they deliver. Therefore, we have tried to be clear with the language we have used to define the people involved (the actors) and their roles, to make our discussion and presentations unambiguous.

Using the terms and defining the roles that each actor takes will help you to gain better insights into the services and products you are delivering. We have shown this in Fig. 1.11 for a project where we were learning about the customer (the installer) and the end-user (the firms who own, operate or maintain the equipment or system). The language in business-to-business (B2B) environments is often challenging, so it is really important we are clear about the terms we use, to help avoid misunderstandings:

- Ecosystem - the whole environment around the company, its suppliers, its customers, its contractors, installers, etc.

- Actors - every person in the ecosystem (e.g., within supply chain or network, etc.)

- Avatars - personifications that represent all the machines in the ecosystem as people.

- Stakeholders (indirect and direct) - the people taking part in the interaction or process either directly or indirectly.

- Beneficiaries (indirect and direct) - the actors who benefit from the integration either directly or indirectly.

- Users - some of the stakeholders and some of the beneficiaries that may be direct users of the products and services. 


\subsection{Seven Barriers Stopping Firms from Moving to Services}

Academic research (Hou \& Neely, 2013) has identified seven types of barriers (or categories of barriers) that are important for manufacturing firms to overcome if they want to develop and deliver new services. Others (e.g., Alghisi \& Saccani, 2015; Martinez et al., 2010; West et al., 2018) have provided more details about the barriers and how firms overcome them. The relative importance of each category is shown in Fig. 1.12. In this book, each of the categories has been broken down into its constituent barriers, detailing problems and difficulties that have been experienced by companies during their journeys. Then, the relative importance of each of these barriers has been defined by the business community we researched (West et al., 2019). Overcoming these barriers is a change management process that requires development of people, capabilities, and processes. It is important to pay close attention to the many potholes that can trip up the unwary. To deliver a strategy, individual managerial actions are necessary to overcome the barriers (Lenka et al., 2018; Lütjen et al., 2017). Therefore, for each of the barriers, case examples have been used to describe how managers have approached the problem. Quotes from managers add more depth to the cases and support the lessons learned. Where appropriate, we have suggested tools that can help you to analyze your situation.

Before considering each of the barriers individually and developing a service excellence roadmap, it is worth a short detour to look at some of the literature and research that have been published.

Customers - This relates to external servitization barriers that need to be overcome. The critical aspects here are linked to sales and gaining access to customers or end-users - both are closely associated with the sales process and the role of "sales" within a firm. This barrier can be experienced through heterogeneous demand (Vandermerwe \& Rada, 1988), together with lack of customers' trust (White et al., 1999) and control over their behaviors (Heiskanen \& Jalas, 2003), making it

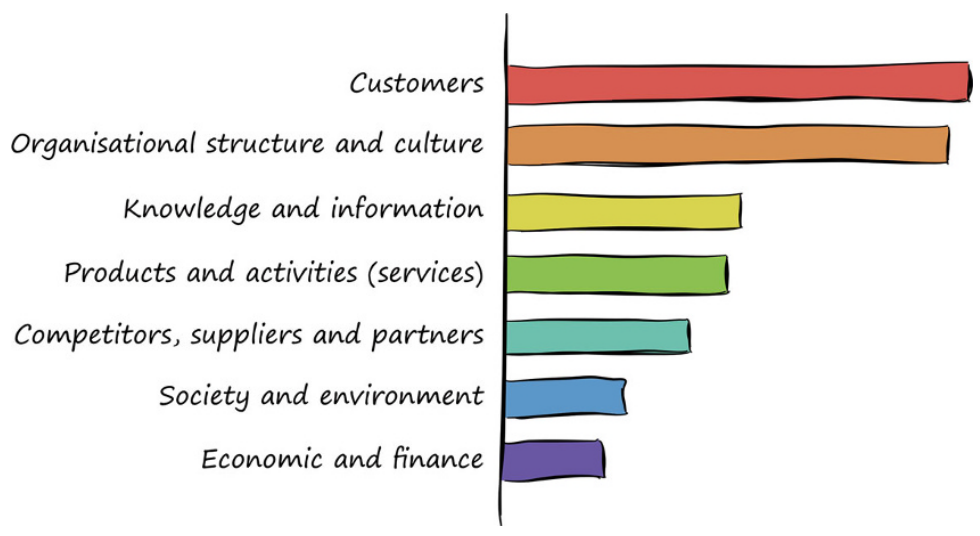

Fig. 1.12 Relative importance of the seven key barriers (illustration by Annick Holland, adapted from West et al., 2018) 
difficult to get cooperation and acceptance from customers (Vandermerwe \& Rada, 1988).

Organizational structure and culture - This barrier deals with internal themes, as servitization business models often face issues from "the management" as well as R\&D or NPD. There are often preconceived thoughts and resistance to change (Vandermerwe and Rada 1988), which make a transition to services difficult. To these are added conflicts among different departments and different hierarchies in organizations. Frequently, the lack of service-based organizational structure (White et al., 1999) and service-oriented culture (Mont, 2002) hinders the transformation process.

Knowledge and information - These are both important in a service business, where much of the knowledge is tacit information (Alghisi \& Saccani, 2014) that is, therefore, difficult to convert into written instructions. A lack of expertise (Brax, 2005) and innovation ability (Kindström et al., 2013), together with difficulties in knowledge and information management (Vandermerwe \& Rada, 1988), complicates the understanding of customer demands and product-service properties (Cook et al., 2002; Mont, 2002).

Products and activities - These were considered less important than the way knowledge and information is shared. On one level, this was surprising, as firms often focus more on their products and activities. In the literature, the lack of competences (Cook et al. 2002) and infrastructures (Maxwell et al., 2006), together with difficulties in designing service packages (or scenarios) and in measuring them (White et al., 1999), makes service design and management more complex.

Competitors, suppliers, and partners - Consolidating the ecosystem is an obstacle for many firms as they discover they are active within complex and competitive environments, involving different actors. This complex multi-actor environment creates difficulties in coordination and cooperation among the increased number of players (Mont, 2002; Vandermerwe \& Rada, 1988).

Economics and finance - Firms need to learn to share benefits and obligations from a win-win perspective. From the economic-financial viewpoint, management is often searching for new revenue models, or ways to report service sales and margins that link to the firm's servitization performance. Often, there is an associated lack of financial competence for early investments (DiPeso, 2000), high risks (Stremersch \& Frambach, 2001), to manage new forms of product-services, unexpected costs, and difficulties in pricing services (Steinberger et al., 2009), leading to ineffective and unprofitable service solutions that drive companies to abandon the business.

Society and environment - Firms often found it hard to move forward from their prior position of delivering services for free. Also, the "think local, act global" approach that was pioneered by ABB in the 1990s remains an issue for firms as they work to both standardize and localize their services. Difficulties in achieving these benefits, which largely depend on circumstances (Mont, 2002), are often based on lack of policy, weak infrastructure support (DiPeso, 2000), and limited incentives (White et al., 1999). All of which undermine managers' confidence by encouraging them to leave the service transformation process. 


\subsection{Further Reading}

For those who would like to go deeper into the subject, the book written by Tim Baines and Howard Lightfoot Made to Serve: How Manufacturers can Compete Through Servitization and Product Service Systems will give you more ideas about how and why manufacturing firms compete with services (Baines et al. 2009; Baines \& Lightfood, 2013). Practices and Tools for Servitization, by Kohtamäki et al. (2018), also provides excellent reading on this topic with insights from many different academics and practitioners. Service Strategy in Action: A Practical Guide for Growing Your B2B Service and Solution Business, by Kowalkowski and Wolfgang (2017), is another useful industrial book written and complements this book, as it is a strategic book rather than an operational one.

Other useful books include This Is Service Design (Thinking/Doing) Stinkdorn et al. (2018), cowritten by Marc Stickdorn (https://www.thisisservicedesigndoing. com), which can help but initially can be a little remote from an industrial perspective. The same can be said about An Introduction to Service Design by Lara Penin (Penin, 2018). Nevertheless, we would recommend buying one or all of them as they support the tools. These are listed and explained in detail in the tools section at the end of this book with useful cases. The Service Design Tools website (https:// servicedesigntools.org) is another good resource to visit.

The Service-Dominant Logic by Vargo and Lusch (2008) is a concept that has been developed from marketing theory over many years to describe or explain value creation, through exchange, among various configurations of actors. It has not been described in depth in this book; nevertheless, some readers may spot links to it in the cases and may wish to read more.

\section{References}

Alghisi, A., \& Saccani, N. (2014). Development of a Knowledge Management framework to support installed base information management practices in a servitized context. In M. Toivonen (Ed.), Proceedings of the 24th International Conference of RESER "Services and New Societal Challenges: Innovation for Sustainable Growth and Welfare” (pp. 28-42). Helsinki, Finland.

Alghisi, A., \& Saccani, N. (2015). Internal and external alignment in the servitization journeyovercoming the challenges. Production Planning and Control. https://doi.org/10.1080/ 09537287.2015.1033496.

Baines, T., \& Lightfood, H. (2013). Made to serve: How manufacturers can compete through servitization and product service systems. London: Wiley.

Baines, T., Lightfoot, H., Peppard, J., Johnson, M., Tiwari, A., Shehab, E., \& Swink, M. (2009). Towards an operations strategy for product-centric servitization. International Journal of Operations and Production Management. https://doi.org/10.1108/01443570910953603.

Brax, S. (2005). A manufacturer becoming service provider - Challenges and a paradox. Managing Service Quality. https://doi.org/10.1108/09604520510585334. 
Confente, I., Buratti, A., \& Russo, I. (2015). The role of servitization for small firms: Drivers versus barriers. International Journal of Entrepreneurship and Small Business, 26(3), 312-331. https:// doi.org/10.1504/IJESB.2015.072394.

Cook, L. S., Bowen, D. E., Chase, R. B., Dasu, S., Stewart, D. M., \& Tansik, D. A. (2002). Human issues in service design. Journal of Operations Management. https://doi.org/10.1016/S02726963(01)00094-8.

DiPeso, J. (2000). P2: Putting environmental issues in a new light. Environmental Quality Management. https://doi.org/10.1002/1520-6483(200023)10:1<13::AID-TQEM3>3.0.CO;2-C.

Dmitrijeva, J., Schroeder, A., Ziaee Bigdeli, A., \& Baines, T. (2020). Context matters: How internal and external factors impact servitization. Production Planning and Control. https://doi.org/10. 1080/09537287.2019.1699195.

Gebauer, H. (2007). The logic for increasing service revenue in product manufacturing companies. International Journal of Services and Operations Management. https://doi.org/10.1504/IJSOM. 2007.013462.

Heiskanen, E., \& Jalas, M. (2003). Can services lead to radical eco-efficiency improvements? - A review of the debate and evidence. Corporate Social Responsibility and Environmental Management. https://doi.org/10.1002/csr.46.

Hou, J., \& Neely, A. (2013). Barriers of servitization: Results of a systematic literature review. In Baines, T., Clegg, B., \& Harrison, D. (Eds.), Spring Servitization Conference. Proceedings of the 2013 Spring Servitization conference "Servitization in the multi-organisation enterprise" (pp. 189-195).

Kindström, D., Kowalkowski, C., \& Sandberg, E. (2013). Enabling service innovation: A dynamic capabilities approach. Journal of Business Research. https://doi.org/10.1016/j.jbusres.2012.03. 003.

Kohtamäki, M., Baines, T., Rabetino, R., \& Bigdeli, A. Z. (2018). Practices and tools for servitization: Managing service transition (pp. 1-429). Springer International. https://doi.org/ 10.1007/978-3-319-76517-4.

Kohtamäki, M., Einola, S., \& Rabetino, R. (2020). Exploring servitization through the paradox lens: Coping practices in servitization. International Journal of Production Economics. https://doi. org/10.1016/j.ijpe.2020.107619.

Kowalkowski, C., Gebauer, H., \& Oliva, R. (2017). Service growth in product firms: Past, present, and future. Industrial Marketing Management. https://doi.org/10.1016/j.indmarman.2016.10. 015.

Kowalkowski, C., \& Ulaga, W. (2017). Service strategy in action: A practical guide for growing your B2B service and solution. Business: Service Strategy Press.

Kowalkowski, C., \& Ulaga, W. (2017). Service strategy in action: A practical guide for growing your B2B service and solution business. Service Strategy Press. https://www.amazon.com/ Service-Strategy-Action-Practical-Solution/dp/069281910X

Kowalkowski, C., \& Witell, L. (2020). Typologies and frameworks in service innovation. In E. Bridges \& K. Frowler (Eds.), The Routledge handbook of service research insights and ideas. Routledge.

Lenka, S., Parida, V., Sjödin, D. R., \& Wincent, J. (2018). Exploring the microfoundations of servitization: How individual actions overcome organizational resistance. Journal of Business Research. https://doi.org/10.1016/j.jbusres.2017.11.021.

Lütjen, H., Tietze, F., \& Schultz, C. (2017). Service transitions of product-centric firms: An explorative study of service transition stages and barriers in Germany's energy market. International Journal of Production Economics. https://doi.org/10.1016/j.ijpe.2017.03.021.

Martinez, V., Bastl, M., Kingston, J., \& Evans, S. (2010). Challenges in transforming manufacturing organisations into product-service providers. Journal of Manufacturing Technology Management. https://doi.org/10.1108/17410381011046571. 
Martinez, V., Neely, A., Urmetzer, F., Allison, N., Lund, M., Buckler, T., Leinster-Evans, S., Pennington G., \& Smith, D. (2016). Seven critical success factors in the shift to services. University of Cambridge, Institute of manufacturing, Cambridge Service Alliance. Accessed January 6, 2020, from https://cambridgeservicealliance.eng.cam.ac.uk/resources/Downloads/ Monthly\%20Papers/SevenCriticalSuccessFactorsintheShifttoServices_ExecBriefing.pdf

Mathieu, V. (2001). Product services: From a service supporting the product to a service supporting the client. Journal of Business and Industrial Marketing. https://doi.org/10.1108/ 08858620110364873.

Maxwell, D., Sheate, W., \& van der Vorst, R. (2006). Functional and systems aspects of the sustainable product and service development approach for industry. Journal of Cleaner Production. https://doi.org/10.1016/j.jclepro.2006.01.028.

Mont, O. K. (2002). Clarifying the concept of product-service system. Journal of Cleaner Production. https://doi.org/10.1016/S0959-6526(01)00039-7.

Penin, L. (2018). An introduction to service design: Designing the invisible paperback. London: Bloomsbury Arts.

Rabetino, R., Kohtamäki, M., \& Gebauer, H. (2017). Strategy map of servitization. International Journal of Production Economics. https://doi.org/10.1016/j.ijpe.2016.11.004.

Schmiedeberg. A, Strähle, O., \& Bendig, O. (2010). Wachstumsmotor Service (Service as a growth motor). Bain \& Company. Accessed January 6, 2021 from https:/www.bain.com/insights/ wachstumsmotor-service/

Schmitt, P., \& Sipen, S. (2017). Services for capital equipment. Roland Berger. Private email.

Steinberger, J. K., van Niel, J., \& Bourg, D. (2009). Profiting from megawatts: Reducing absolute consumption and emissions through a performance-based energy economy. Energy Policy. https://doi.org/10.1016/j.enpol.2008.08.030.

Stinkdorn, M., Edgar Hormess, M., Lawrence, A., \& Schneider, J. (2018). This is service design doing. New York: O'Reilly.

Stremersch, S., \& Frambach, R. T. (2001). The purchasing of full-service contracts: Maintenance market. Industrial Marketing Management, 30(1), 1-12.

Tukker, A. (2004). Eight types of product-service system: Eight ways to sustainability? Experiences from suspronet. Business Strategy and the Environment. https://doi.org/10.1002/bse.414.

Vandermerwe, S., \& Rada, J. (1988). Servitization of business: Adding value by adding services. European Management Journal. https://doi.org/10.1016/0263-2373(88)90033-3.

Vargo, S. L., \& Lusch, R. F. (2008). Service-dominant logic: Continuing the evolution. Journal of the Academy of Marketing Science. https://doi.org/10.1007/s11747-007-0069-6.

West, S., \& Gaiardelli, P. (2016). Driving the servitization transformation through change management: lessons learnt from industrial cases. In T. Baines, J. Burton, D. Harrison, \& J. Zolkiewski (Eds.), Proceedings of the 2016 Spring Servitization Conference 2016 "Servitization: Shift, Transform, Grow”. Manchester Business School.

West, S., Gaiardelli, P., Bigdeli, A., \& Baines, T. (2018). Exploring operational challenges for servitization: An European survey. In A. Bigdeli, T. Frandsen, J. Raja, \& T. Baines (Eds.), Proceedings of 2018 Spring Servitization Conference "Driving Competitiveness through Servitization" (pp. 9-17).

West, S. Gaiardelli, P., \& Mathews, A. (2019). Overcoming the challenges of change management associated with servitization: Lessons from 20 practical cases. In Bigdeli, Kowalkowski, Kindström, and Baines (Eds.), Proceedings of 2018 Spring Servitization Conference "The Spring Servitization Conference 2019: Delivering Services Growth in the Digital Era" (pp. 9-17). 
West, S., \& Pascual, A. (2015). The use of equipment life-cycle analysis to identify new service opportunities. In T. Baines \& D. Harrison (Eds.), Proceedings of the 2015 Spring Servitization Conference 2016. Aston, UK: Aston Business School.

West, S., Schmitt, P., \& Siepen, S. A. (2014). A comparative assessment of the service cultures of industrial businesses in the DACH region of Europe and their impact on business performance. In Proceedings of the 2014 EUROMA Conference "Operations Management in an Innovation Economy", Palermo June 2014.

West, S., Stoll, O., \& Mueller-Csernetzky, P. (2020). 'Avatar journey mapping' for manufacturing firms to reveal smart-service opportunities over the product life-cycle. International Journal of Business Environment. https://doi.org/10.1504/IJBE.2020.110906.

White, A., Stoughton, M., \& Feng, L. (1999). Servicizing: The quiet transition to extended product responsibility. Table, (May), 1-97.

Open Access This chapter is licensed under the terms of the Creative Commons Attribution 4.0 International License (http://creativecommons.org/licenses/by/4.0/), which permits use, sharing, adaptation, distribution and reproduction in any medium or format, as long as you give appropriate credit to the original author(s) and the source, provide a link to the Creative Commons license and indicate if changes were made.

The images or other third party material in this chapter are included in the chapter's Creative Commons license, unless indicated otherwise in a credit line to the material. If material is not included in the chapter's Creative Commons license and your intended use is not permitted by statutory regulation or exceeds the permitted use, you will need to obtain permission directly from the copyright holder.

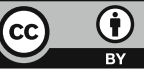

